\title{
Prakriti (Ayurvedic concept of constitution) and variations in platelet aggregation
}

\author{
Supriya Bhalerao ${ }^{1}$, Tejashree Deshpande ${ }^{1}$ and Urmila Thatte $2^{2^{*}}$
}

\begin{abstract}
Background: Ayurveda, the Indian traditional system of medicine describes a unique concept "prakriti", genetically determined, categorising the population into several subgroups based on phenotypic characters like appearance, temperament and habits. The concept is claimed to be useful in predicting an individual's susceptibility to a particular disease, prognosis of that illness and selection of therapy. The present study was carried out to study if the platelet aggregatory response and its inhibition by aspirin varied in the different prakriti subtypes.

Methods: After obtaining Institutional Ethics Committee permission, normal healthy individuals of either sex between the age group 18 to 30 years were recruited in the study. Their prakriti evaluation was done using a standardized validated questionnaire (TNMC Prakriti 2004). Their Platelet Rich Plasma was incubated with either aspirin [2.5micro-mole $(\mu \mathrm{M})$ and $5 \mu \mathrm{M}]$ or distilled water as control for three minutes after which the aggregatory response to $5 \mu \mathrm{M}$ Adenosine Diphosphate (ADP) was measured over a period of 7 minutes.
\end{abstract}

Results: We observed that in the study population of normal healthy participants ( $n=137$ ), ADP-induced maximal platelet aggregation (MPA) was highest among the Vata-pitta prakriti individuals [Median (range), 83.33\% (52.33-96)] as compared to the other prakriti types and these individuals responded better to lower dose of aspirin compared to other prakriti types.

Conclusions: Our results suggest that identifying the prakriti may help in individualising therapy or predicting proneness to a disease.

Keywords: Adenosine diphosphate, Aspirin, Pitta, Kapha, Vata

\section{Background}

Ayurveda, the Indian traditional system of medicine [1] describes a unique concept "prakriti" [2] (constitution), which is genetically determined, categorising the population into several subgroups based on phenotypic characters like appearance, temperament and habits. The concept is claimed to be useful in predicting an individual's susceptibility to a particular disease, prognosis of that illness and selection of therapy [3].

Ayurveda attributes these constitutional characteristics of an individual to the preponderance of certain "doshas". Three main doshas are described, viz. vata, pitta and kapha. Kapha dosha is the "anabolic", synthetic dosha, responsible for growth and maintenance of structure [4]. The pitta dosha is the one responsible for

\footnotetext{
* Correspondence: urmilathatte@kem.edu

${ }^{2}$ Dept. of Clinical Pharmacology, Seth GS Medical College and KEM Hospital, Parel, Mumbai 400 012, India

Full list of author information is available at the end of the article
}

metabolism, including digestion in the gut, and cellular or sub-cellular metabolism. Vata dosha is responsible for movement (muscular, nervous energy etc.). Based on the predominance of individual doshas, there are three major types of prakriti named after predominant dosha, viz., vata, pitta and kapha. The prakriti is believed to be determined at the time of conception and is influenced by the milieu interior of the womb and the dietary habits and lifestyle of the mother [5]. These prakritis exhibit attributes of the dominant Dosha in physical, physiological and psychological characteristics. The disturbance in equilibrium of these doshas can lead to disease according to the prakriti of the person for example; a pitta prakriti person is described to be more prone to peptic ulcers, hypertension, and skin diseases, a vata prakriti person to backache, joint aches and crackling joints while individuals with kapha prakriti are prone to obesity, diabetes and atherosclerosis [6-8].

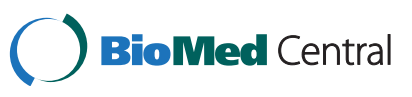


Various studies have tried to establish whether specific prakriti individuals show specific groupings according to anthropometric measurements and biochemical variables like serum cholesterol, blood sugar or blood groups [9]. Recently a study reported complete absence of the HLA DRB1*02 allele in the Vata type and of HLA DRB1*13 in the Kapha type. Higher allele frequency of HLA DRB1*10 was noted in the Kapha type than in the Pitta and Vata types [10].

In another study, the differences in the whole gene expression among the various prakriti subtypes have also been explored. The functional categories of genes showing differential expression among Prakriti types were significantly enriched in core biological processes like transport, regulation of cyclin dependent protein kinase activity, immune response and regulation of blood coagulation. A significant enrichment of housekeeping, disease related and hub genes were also observed in the three extreme constitution types [2].

In our earlier studies we found a specific type of prakriti was predominant in epileptic or hypertensive individuals as compared to normal healthy individuals [7]. Platelet reactivity, the phenomenon that markedly influences the pathological outcome of thrombosis and sensitivity to anti-platelet drugs, has been reported to exhibit individual/genetic variations [11]. Since prakriti has been described to have genetic origin in Ayurvedic texts [5] we thought it would be interesting to study whether platelet aggregation in response to ADP and its inhibition with aspirin varies in the different prakriti sub-types.

\section{Methods}

\section{Ethics}

The study was initiated after obtaining permission from Institutional Ethics Committee, BYL Nair Ch. Hospital \& TN Medical College, Mumbai and conducted according to the principles enunciated in the Declaration of Helsinki (2008) [available at http://www.wma.net/en/ 30publications/10policies/b3/index.html last accessed on $8^{\text {th }}$ June 2012] and the ICMR's Ethical Guidelines for Biomedical Research in Human Participants [available at http://icmr.nic.in/ethical_guidelines.pdf last accessed on $8^{\text {th }}$ June 2012]. Only those participants who gave written informed consent were recruited.

\section{Study population}

Normal healthy individuals (confirmed by history, physical examination and routine laboratory investigations, including hematology, renal and liver function tests) between the age group of 18 to 30 years (both years inclusive) of either sex, and willing to abide by trial procedures were enrolled.

\section{Prakriti assessment}

Prakriti was assessed using a multiple-choice questionnaire (Additional file 1: TNMC Prakriti 2004) which was designed on the basis of literature in Ayurvedic texts comprising 37 objective questions related to the person's physical characteristics, psychological make-up and physiological habits (Table 1). Each of the questions had three options to choose from referring to a property attributed to Vata (V), Pitta (P) or Kapha (K). The score obtained by a person for answers in the V, P and $\mathrm{K}$ domain were summed up and the person was identified as having a specific prakriti depending on scores obtained. When a participant scored $\geq 50 \%$ on a particular dosha, that was considered as the predominant dosha, whereas a score between 25\%-35\% categorised the dosha as the secondary dosha in the prakriti. For example, when a participant scored 20 (54\%) for the Pitta dosha and 13 (32\%) for the Kapha dosha, he was categorised as a Pitta-Kapha prakriti. On the other hand if the score was 22 (59\%) for the Kapha dosha and 12 (32\%) for the Pitta dosha, he was categorised as Kapha-Pitta prakriti.

\section{Validation of questionnaire}

The questionnaire was validated by pre-testing where the results obtained by the questionnaire were confirmed by the clinical assessment of the prakriti independently by two Ayurveda physicians in 30 participants. More than 90\% concordance was observed in the prakriti assessment by the two clinicians as well as by the questionnaire.

\section{Evaluation of prakriti in participants}

For the study, the prakriti of each volunteer was assessed using the validated questionnaire (Additional file 1: TNMC Prakriti 2004). It was further confirmed by an Ayurvedic physician (first author) following a traditional algorithm (based on interview and a physical examination) to assess various physical, physiological and psychological characters as described in Ayurvedic texts [5].

The individual was classified into vata-pitta, vatakapha, pitta-kapha, pitta-vata, kapha-pitta or kaphavata prakriti.

Table 1 Demographic details $(n=137)$

\begin{tabular}{|c|c|c|c|}
\hline Prakriti & $n(M: F)$ & Age (years) & BMI $\left(\mathrm{kg} / \mathrm{m}^{2}\right)$ \\
\hline Vata-Kapha & $4(1: 3)$ & $23 \pm 1.22$ & $18.99 \pm 2.57$ \\
\hline Vata-Pitta & $16(7: 9)$ & $22.94 \pm 2.08$ & $19.71 \pm 2.47^{*}$ \\
\hline Pitta-Kapha & $65(32: 33)$ & $23.08 \pm 1.71$ & $21.81 \pm 2.67$ \\
\hline Pitta-Vata & $12(7: 5)$ & $23.25 \pm 2.45$ & $20.37 \pm 2.79$ \\
\hline Kapha-Vata & $4(1: 3)$ & $23.50 \pm 2.08$ & $20.34 \pm 2.21$ \\
\hline Kapha-Pitta & $36(19: 17)$ & $23.14 \pm 2.28$ & $23.42 \pm 3.89$ \\
\hline
\end{tabular}




\section{Platelet aggregation study}

Platelet aggregatory response to ADP was studied using the turbidometric method described by Born [12] on a Chronolog platelet aggregocorder. Briefly, $9 \mathrm{ml}$ blood was collected from each volunteer in a polystyrene tube containing $1 \mathrm{ml}$ of $3.8 \%$ sodium citrate. Platelet rich plasma (PRP) was obtained as a supernatant by centrifugation (1000 rpm for 10 mins at $25^{\circ} \mathrm{C}$ ) and the remaining blood was centrifuged again (4000 rpm for 15 mins at $25^{\circ} \mathrm{C}$ ) to obtain platelet poor plasma (PPP). Platelets in the PRP were counted using a platelet counter and the count was adjusted to $2 \times 10^{5} / \mathrm{L}$ using autologus PPP for dilution. This plasma was incubated with either aspirin $(2.5 \mu \mathrm{M}$ and $5 \mu \mathrm{M})$ or distilled water as control for three minutes after which the aggregatory response to $5 \mu \mathrm{M}$ Adenosine Diphosphate (ADP) was measured over a period of 7 minutes. The percent aggregation at this time point was defined as the Maximal Platelet Aggregation (MPA). dMPA was calculated by subtracting \% MPA with aspirin from \% MPA with distilled water.

\section{Reproducibility of platelet aggregation studies}

Platelet aggregation studies were repeated thrice at an interval of 15 days in the initial 76 participants to identify whether there was variability in platelet aggregation over a period of time. Results suggested that there was no significant variation in platelet function over time and hence platelet aggregation was studied only once in the rest of the participants $(n=61)$. The average of the three readings of the initial 76 participants was used for analysis.

\section{Statistical analysis}

In the absence of any preliminary data, no formal sample size calculation was performed.

The data was expressed as Mean \pm SD, 95\% CI if distributed normally and was analysed using One-way ANOVA followed by Tukey's post-hoc test. The data was expressed as Median (Range) if not normally distributed and was analysed using Kruskal Wallis followed by Dunn's post-hoc test. Graphpad Instat software, version 3.06 was used for all analyses. The level of significance for all analysis was taken as $\mathrm{p}<0.05$. Two prakriti types viz. Vata-kapha and kapha-vata could not be considered for statistical analysis because of too few values in these groups.

\section{Results}

A total of 137 participants were recruited in the study. The distribution of these volunteers according to Prakriti along with their demographic data is shown in Table 1. The age and sex distribution of the participants amongst the 3 prakrti types was comparable. Interestingly, the BMI in vata-pitta prakriti was significantly less as compared to kapha-pitta prakriti.

Although the vata-pitta prakriti individuals had the maximum MPA as compared to other prakriti individuals (Table 2) this was not statistically significant. After incubation with 2.5 or $5 \mu \mathrm{M}$ aspirin, \% MPA in all prakriti types was comparable.

The largest change (dMPA) in the MPA after aspirin was noted in the vata-pitta prakriti individuals followed by those with kapha-vata and pitta-vata prakriti. Individuals with pitta-kapha and kapha-prakriti showed the least inhibition of platelets at $2.5 \mu \mathrm{M}$ concentration. This was significantly less than that in individuals with vatapitta prakriti $(\mathrm{p}<0.05)$. However, at $5 \mu \mathrm{M}$ aspirin, no difference was observed amongst prakriti types suggesting that a plateau effect was reached with aspirin (Table 3).

\section{Discussion}

We found in our cohort of normal healthy individuals that platelet aggregation induced by ADP and the inhibitory effect of aspirin differed according to prakriti. Thus, vata-pitta prakriti individuals had the maximum MPA as compared to other prakriti types. These individuals also demonstrated largest dMPA after exposure to $2.5 \mu \mathrm{M}$ aspirin.

According to Ayurveda, Vata dosha is reported to be responsible for a quick response or rapid movement, whereas Pitta dosha is described as the dosha responsible for metabolic activities (platelet aggregation occurs secondary to tremendous enzymatic activity within and around the platelets). These properties of doshas probably are also reflected in cellular responses. In our study too the vata-pitta prakriti individuals had the maximum platelet aggregation.

Table 2 ADP $(5 \mu \mathrm{M})$ induced \% Maximal platelet aggregation (\%MPA) ( $\mathrm{n}=137)$ with or without aspirin [Median (Range)]

\begin{tabular}{|c|c|c|c|}
\hline Prakriti & Distilled water & With Aspirin $2.5 \mu \mathrm{M}$ & With Aspirin $5 \mu \mathrm{M}$ \\
\hline Vata-Kapha & $86(57-93)$ & $52(44-59)$ & $55.33(28-70)$ \\
\hline Vata-Pitta & $83.33(52.33-96)$ & $49(32-91)$ & $51.50(25.67-79)$ \\
\hline Pitta-Kapha & $78(20-115.33)$ & $58.17(14-88.33)$ & $48(5-78)$ \\
\hline Pitta-Vata & $69.50(56.33-106)$ & $50.50(29-84)$ & $44(20-60)$ \\
\hline Kapha-Vata & 77.50 (69-82) & $51.50(44-57)$ & $41.17(38-48)$ \\
\hline Kapha-Pitta & $72(35.67-98)$ & $51.67(22-86)$ & $40(14.67-68)$ \\
\hline
\end{tabular}


Table 3 dMPA according to prakriti ( $n=137)$ [Median (Range)]

\begin{tabular}{lcc}
\hline \multirow{2}{*}{ Prakriti } & \multicolumn{2}{c}{ Concentrations of Aspirin } \\
\cline { 2 - 3 } & $\mathbf{2 . 5 \mu \mathrm { M }}$ & $\mathbf{5} \boldsymbol{\mu M}$ \\
\hline Vata-Kapha & $29(13-44)$ & $29.17(23-32)$ \\
\hline Vata-Pitta & $31.83(3-57)$ & $27.83(11-51)$ \\
\hline Pitta-Kapha & $18(3-48)^{*}$ & $27.33(14-64)$ \\
\hline Pitta-Vata & $19.33(12-40)$ & $29.5(21.33-49)$ \\
\hline Kapha-Vata & $22.67(18.67-38)$ & $32.83(28-44)$ \\
\hline Kapha-Pitta & $16.67(6-60)^{*}$ & $27.33(9-71)$
\end{tabular}

${ }^{*} \mathrm{p}<0.05$ as compared to vata-pitta prakriti using Kruskal-Wallis test followed by Dunn's post-test.

Our data further shows that presence of kapha dosha lowers the aggregatory response. According to Ayurveda, Kapha dosha leads to slow metabolism [5] which may be reflected as a slower platelet aggregatory response.

Interestingly, our study highlights the subjective nature of prakriti analysis indicating it is difficult to quantify the influence of each dosha on the platelet response objectively e.g. pitta-kapha prakriti participants had a median MPA of 78 with a range of as low as 20 (perhaps this participant had a higher kapha influence) to as high as 115 (perhaps having higher pitta influence), while individuals with the kapha-pitta prakriti (who have combination of the same 2 doshas in different proportions) had a median MPA of 72 with a range of only 35.67 to 98 suggesting that the dominant kapha dosha in these participants tended to keep the aggregatory response low on the whole. These findings suggest that the predominant dosha determining prakriti might be playing major role in the process of platelet aggregation. However, these findings need to be confirmed in a larger sample size with thorough quantitative analysis of prakriti determining doshas.

It is also important to note that ADP induced platelet aggregation is a complex process in vivo, influenced by various factors including levels of endogenous ADP, cGMP and Arachidonic acid, blood viscosity [13] and family history [14]. Therefore, the results of our study may not reflect the in vivo situation.

ADP is known to be central amongst agonists of platelet aggregation that act upon surface expressed G protein-coupled receptors $\mathrm{P}_{2} \mathrm{Y}_{1}$ and $\mathrm{P} 2 \mathrm{Y}_{12}$. A recent study [15] has demonstrated that $\mathrm{P}_{2} \mathrm{Y}_{12} \mathrm{H} 2$ haplotype is associated with the maximal aggregation response to ADP [14]. Intra-individual differences in anti-platelet effect of aspirin have also been reported and association of these differences with polymorphisms in the genes coding for cyclo-oxygenase-1 (COX-1) and several platelet glycoprotein (GP) receptors have also been studied [16].

Patwardhan et al [17] have shown that the extensive metabolizer (EM) genotype of the drug metabolizing enzyme CYP2C19 ("1/*3) was found only in Pitta Prakriti. The higher metabolic capacity of the pitta prakriti is similar to the higher platelet aggregation associated with pitta in our study. It would be therefore interesting to study whether the differences we observed in the present study are due to the genetic variations amongst prakriti types.

A possible limitation of our study is unequal number of individuals in different prakriti types and the small sample size $(\mathrm{n}=4)$ in vata-kapha and kapha-vata types, Further, there is evidence that the inter-individual differences in platelet aggregatory response to ADP are more pronounced at lower concentrations of ADP $(1,2$ or $5 \mu \mathrm{M})$ [15]. Hence, to detect the variations in \%MPA amongst prakriti subtypes, study of platelet aggregation using 1 and $2 \mu \mathrm{M}$ ADP may prove more useful.

A recent study has shown that there is association between blood group of individual and risk of heart disease [18]. Although we have not done blood grouping of volunteers recruited in our study, it would be worth exploring whether blood groups have any association with Prakriti as well. This association can prove an important bridge between Ayurvedic and modern medical concepts.

The findings of our study however can have implications with respect to pharmacogenomics \& study of doseresponse relationships. These findings can also prove useful for the randomization in clinical trial design, as randomization would be best within the specific prakriti or dosha predominant sub-groups than across an aggregated population.

\section{Conclusions}

Our study for the first time documents prakriti related variations in platelet aggregation response in healthy individuals.

\section{Additional file}

Additional file 1: TNMC Prakriti 2004 Questionnaire.

Abbreviation

Nil: (explained in text).

Competing interests

Authors declare that there is no competing financial interest in relation to the work described.

\section{Authors' contributions}

SB: Design of the study, analysis and interpretation of data, drafting the manuscript. TD: Acquisition of data. UT: Conception and design, interpretation of data, revising the manuscript critically for intellectual content. All authors read and approved the final manuscript.

\section{Acknowledgements}

The authors acknowledge the financial support received from Department of AYUSH, Govt. of India for carrying out the study. 


\section{Author details}

'Dept. of Clinical Pharmacology, TN Medical College \& BYL Nair Ch. Hospital, Mumbai Central, Mumbai 400 008, India. ${ }^{2}$ Dept. of Clinical Pharmacology, Seth GS Medical College and KEM Hospital, Parel, Mumbai 400 012, India.

Received: 23 July 2012 Accepted: 7 December 2012

Published: 10 December 2012

\section{References}

1. Dahanukar SA, Thatte UM: 'Historical survey of the evolution of Ayurveda', Chapter 2 in Ayurveda Revisited. 1st edition. Popular Prakashan Mumbai; 2000:10-27. reprint.

2. Prasher B, Negi S, Aggarwal S, Mandal AK, Sethi TP, Deshmukh SR, Purohit SG, Sengupta S, Khanna S, Mohammad F, Garg G, Brahmachari SK: Indian Genome Variation Consortium, Mukerji M; 'Whole genome expression and biochemical correlates of extreme constitutional types defined in Ayurveda'. $J$ Transl Med 2008, 6:48. www.translationalmedicine.com/content/1/6/48.

3. ' $11^{\text {th }}$ Adhyaya'. 5th edition. Edited by Sutra S, Charak S, Vd. Jadavji Trikamji Acharya. Varanasi: Chaukhamba Sanskrit Sansthan; 2001:66.

4. Dahanukar SA, Thatte UM: The rulers: Doshas' Chapter 3 in Ayurveda Unraveled. 1st edition. New Delhi: National Book Trust; 1996:13-25.

5. ' $8^{\text {th }}$ Adhyaya'. 5th edition. Edited by Viman S, Charak S, Vd. Jadavji Trikamji Acharya. Varanasi: Chaukhamba Sanskrit Sansthan; 2001:277.

6. '8th Adhyaya'. 5th edition. Edited by Sutra S, Charak S, Vd. Jadavji Trikamji Acharya. Varanasi: Chaukhamba Sanskrit Sansthan; 2001:66.

7. Svoboda RE: 'Constitutional characteristics'; Chapter 2 in Prakriti: Your Ayurvedic constitution. 1st edition. 1996:49-54, reprint.

8. Bhalerao SS, Pawse P: Chapter 2 "Concept of Prakriti". In Dr. Sharadini Dahanukar-Ayurveda Centre for Research, Training and Services. 1st edition. 1996:15.

9. Baghel MS: Research in Ayurveda: A directory of all India PG and PhD theses of Ayurveda' $2^{\text {nd }}$ edition. Jamnagar: Mridu Ayurvedic Publications; 2005.

10. Patwardhan B, Joshi K, Chopra A: Classification of human population based on HLA gene polymorphism and the concept of prakriti in Ayurveda. J Altern Complement Med 2005, 11(2):349-353.

11. Bray PF: Platelet Reactivity and Genetics Down On The Pharm. Trans Am Clin Climatol Assoc 2006, 117:103-111.

12. Born GVR: Aggregation of blood platelets by adenosine diphosphate and its reversal. Nature 1962, 194:927-929.

13. O'Donnell K, Larson MG, Feng D, Sutherland PA, Myers RH, D'Agostino RA, Levy D, Tofler GH: Genetic and Environmental Contributions to Platelet Aggregation: The Framingham Heart Study. Circulation 2001, 103:3051-3056.

14. Nara Y, Kihara M, Nabika T, Mano M, Horie R, Yamori Y: Dietary effect on platelet aggregation in men with and without a family history of essential hypertension. Hypertension 1984, 6:339-343.

15. Fontana P, Dupont A, Gandrille S: Adenosine Diphosphate-induced Platelet aggregation is associated with $\mathrm{P} 2 \mathrm{Y} 12$ gene sequence variations in healthy subjects. Circulation 2003, 108:989-995.

16. Lepäntalo A, Mikkelsson J, Reséndiz JC, Viiri L, Backman JT, Kankuri E, Karhunen PJ, Lassila R: Polymorphisms of COX-1 and GPVI associate with the antiplatelet effect of aspirin in coronary artery disease patients. Thromb Haemost 2006, 95(2):253-259.

17. Yogita G, Kalpana J, Bhushan P: Traditional Medicine to Modern Pharmacogenomics: Ayurveda Prakriti Type and CYP2C19 Gene Polymorphism Associated with the Metabolic Variability. Evid Based Complement Alternat Med 2011, 2011:5. doi:10.1093/ecam/nep206. Article ID 249528.

18. He M, Wolpin B, Rexrode K, et al: ABO Blood Group and Risk of Coronary Heart Disease in Two Prospective Cohort Studies. Arterioscler Thromb Vasc Biol 2012, 32:2314-2320.

doi:10.1186/1472-6882-12-248

Cite this article as: Bhalerao et al:: Prakriti (Ayurvedic concept of constitution) and variations in platelet aggregation. BMC Complementary and Alternative Medicine 2012 12:248.

\section{Submit your next manuscript to BioMed Central and take full advantage of:}

- Convenient online submission

- Thorough peer review

- No space constraints or color figure charges

- Immediate publication on acceptance

- Inclusion in PubMed, CAS, Scopus and Google Scholar

- Research which is freely available for redistribution

Submit your manuscript at www.biomedcentral.com/submit
Ciomed Central 